Удк 616-005.6/.7-06:617.55-06:616.147.2/3

DOI 10.11603/2414-4533.2016.3.6796

(С) Т. В. РОМАНЮК, С. Й. ЗАПОРОЖАН, А. В. МАХНІЦЬКИЙ, А. Є. БУРАК, Л. Р. НАЗАРКО

дВНЗ “Тернопільський державний медичний університет імені І. Я. Горбачевського”

\title{
Комплексна профілактика тромбоемболічних ускладнень у хворих із гострою хірургічною абдомінальною патологією, поєднаною з хронічними захворюваннями вен нижніх кінцівок
}

\author{
T. V. ROMANIUK, S. Y. ZAPOROZHAN, A. V. MAHNITSKYI, A. YE. BURAK, L. R. NAZARKO \\ I. Horbachevsky Ternopil State Medical University
}

\section{COMPLEX PREVENTION OF THROMBOEMBOLIC COMPLICATIONS IN PATIENTS WITH ACUTE ABDOMINAL SURGICAL PATHOLOGY COMBINED WITH CHRONIC VENOUS DISEASE OF LOWER EXTREMITIES}

\begin{abstract}
У роботі вивчено вплив комплексної антикоагулянтної профілактики тромбоемболічних ускладнень у хворих із гострою хірургічною абдомінальною патологією, поєднаною з хронічними захворюваннями вен нижніх кінцівок, на зміни коагуляції та тканинної мікроциркуляції. Виявлено суттєве покращення тканинної мікроциркуляції за рахунок медикаментозної гіпокоагуляції, зниження ризиків тромбоемболічних ускладнень.

The work studied the effect of anticoagulant comprehensive prevention of thromboembolic complications in patients with acute abdominal surgical pathology combined with chronic venous disease of lower extremities for changes in coagulation and tissue microcirculation. It was found out significant improvement tissue microcirculation by drug hypocoagulation, reducing the risk of thromboembolic complications.
\end{abstract}

Постановка проблеми і аналіз останніх досліджень та публікацій. Щорічно від тромбоемболічних ускладнень у світі помирає близько 3 млн хворих, в Європі більше 500 тис. осіб [3]. В Україні щорічно реєструють 50 тис. випадків ТЕЛА (0,11\% популяції), із яких понад 10 тис. хворих помирають [1]. Поширеність тромбозу сильно коливається у пацієнтів різного віку. Так, наприклад, на 100 тис. пацієнтів молодого віку діагностують лише 5 випадків тромбозу, а на 100 тис. пацієнтів похилого віку вже 450-600, що, безумовно, пов’язано зі скомпрометованістю хронічними захворюваннями венозної системи нижніх кінцівок, органів малого таза [2, 5]. Необхідно відмітити, що ризики венозного тромбоемболізму вищі у хворих із гострою хірургічною абдомінальною патологією. За даними аутопсій, тромбоз виявляють у 12 \% усіх хірургічних пацієнтів, а у тих же пацієнтів, однак похилого віку, його виявляють уже в 20 \% [4].

Сучасна стратегія застосування антикоагулянтів дозволила зменшити летальність від ТЕЛА до 2-8 \% [6-7].

Мета роботи: дослідити ефективність комплексної профілатики тромбоемболічних усклад- нень у хворих з ургентною абдомінальною патологією, поєднаною з хронічними захворюваннями вен нижніх кінцівок.

Матеріали і методи. У дослідженні взяли участь пацієнти (n=34) із гострою хірургічною абдомінальною патологією, поєднаною 3 посттромботичним синдромом нижніх кінцівок. Для чистоти дослідження відбирали лише прооперованих пацієнтів. Усі пацієнти із посттромботичним синдромом нижніх кінцівок у стадії реканалізації початкової чи повної. Про ефективність комплексної профілактики тромбоемболічних ускладнень у хворих з ургентною абдомінальною патологією, поєднаною 3 хронічними захворюваннями вен нижніх кінцівок, судили по прямих змінах - в коагулограмі крові пацієнтів, а також по непрямих зміні реологічних властивостей крові. Останнє досліджували шляхом визначення змін кровотоку на рівні мікроциркуляторного русла. Для цього використали метод фотоплетизмографії тканин нижніх кінцівок. Фотоплетизмографію мікроциркуляторного русла досліджували за допомогою пульсоксиметра NANOXесо. В основі методу лежить 
вимірювання поглинання світла визначеної хвилі гемоглобіном крові. Результат репрезентувався у вигляді кривої на моніторі, згідно з якою вираховували фотоплетизмографічний індекс (ФI), індекс еластичності (IE), капілярний градієнт (КГ). Якщо ФI та IE відображали стан мікроциркуляції в спокої, то КГ - динамічну функцію мікроциркуляторного русла при навантаженні. Дослідження проводили безпосередньо до операції та порівнювали зі змінами на третю добу післяопераційного періоду.

Результати досліджень та їх обговорення. У комплексі профілактики тромбоемболічних ускладнень поряд з обов'язковою еластичною компресією нижніх кінцівок застосовували комбіновану медикаментозну корекцію. Антикоагулянтну корекцію проводили беміпарином з розрахунку 115 МО на 1 кг один раз на добу.

При первинному обстеженні хворих визначено показники коагуляційного гемостазу і фібринолітичної активності плазми крові у групах хворих. Останні порівняли з післяопераційними показниками (табл. 1).

Аналізуючи отримані дані, можна встановити, що у пацієнтів до операції були підвищені значення фібриногену на 28,0 \%, протромбінового індексу - на 14,6 \%, подовження протромбінового часу
- на 17,86 \%, скорочення тромбінового часу - на 22,5 \%, АЧТЧ - на 30,0 \%, тобто мала місце гіперкоагуляція - підвищення ризиків тромбоемболічних ускладнень. Водночас зниження плазміну на 25,7 \% та подовження часу Хагеман-залежного фібринолізу на 17,7 \% свідчить про недостатність системи фібринолізу та про виснаження їх механізмів хронічним процесом у венозній системі нижніх кінцівок.

Застосування комплексної профілактики тромбоемболічних ускладнень уже на третю добу суттєво змінило показники коагулограми доопераційного періоду. Так, знизився рівень фібриногену до нормального, нормалізувався АЧТЧ. Протромбіновий час скоротився більш ніж удвічі, а тромбіновий подовшився на 56,4 \%, що загалом свідчить про гіпокоагуляцію. Застосовувана корекція позитивно вплинула на процеси фібринолізу. Суттєво підвищився плазмін у крові на 32,2 \%, скоротився час Хагеман-залежного фібринолізу на 24,5 \%, i, як результат, - зросли Д-димери плазми крові на 38,78 \%.

Виявлені зміни, безумовно, впливають на макро-, мікрогемодинаміку в ураженій патологічним процесом кінцівці. Тому з метою визначення впливу коагуляційних та гемодинамічних факторів на мікроциркуляцію використано методику фотоплетизмографії (табл. 2).

Таблиця 1. Стан коагуляційного гемостазу і фрібринолітичної активності плазми крові (X士m)

\begin{tabular}{||l|c|c|c||}
\hline \multicolumn{1}{|c|}{ Показник } & Норма & $\begin{array}{c}\text { Доопераційні } \\
\text { показники }\end{array}$ & $\begin{array}{c}\text { Післяопераційні } \\
\text { показники (3 доба) }\end{array}$ \\
\hline Фібриноген, г/л & $1,5-3,75$ & $4,8 \pm 0,6$ & $3,5 \pm 0,9$ \\
\hline Протромбіновий час, с & $10-14$ & $16,5 \pm 0,6$ & $8,2 \pm 2,0$ \\
\hline Тромбіновий час, с & $8-14$ & $6,2 \pm 1,0$ & $9,7 \pm 1,1$ \\
\hline АЧТЧ, с & $26-36$ & $18,2 \pm 0,8$ & $29,8 \pm 1,4$ \\
\hline Протромбіновий індекс, \% & $80-105$ & $120,3 \pm 5,2$ & $693,9 \pm 44,4$ \\
\hline Д-димери, нг/мл & $<500$ & $481,3 \pm 32,6$ & $103,1 \pm 3,9$ \\
\hline Плазмін, \% & $105,3 \pm 4,0$ & $78,0 \pm 3,6$ & $17,6 \pm 2,3$ \\
\hline Час Хагеман-залежного фібринолізу, хв & $19,8 \pm 0,7$ & $23,3 \pm 1,4$ & \\
\hline
\end{tabular}

Таблиця 2. Вихідні показники мікроциркуляції та кисневого забезпечення (X士m)

\begin{tabular}{||l|c|c|c||}
\hline \multicolumn{1}{|c|}{ Показник } & Норма & $\begin{array}{c}\text { Доопераційні } \\
\text { показники }\end{array}$ & $\begin{array}{c}\text { Післяопераційні } \\
\text { показники (3 доба) }\end{array}$ \\
\hline Фотоплетизмографічний індекс, \% & $50 \pm 2,3$ & $23,4 \pm 1,9$ & $43,7 \pm 3,1$ \\
\hline Індекс еластичності, \% & $50 \pm 2,4$ & $27,3 \pm 2,6$ & $36,2 \pm 2,6$ \\
\hline Капілярний градієнт, \% & $50 \pm 2,1$ & $23,8 \pm 2,1$ & $38,4 \pm 2,4$ \\
\hline \hline
\end{tabular}

Найменше зниження від норми фотоплетизмографічного індексу - 53,2 \%, індексу еластичності - 54,6 \%, капілярного градієнта - 47,6 \% відмічено у хворих в доопераційному періоді. Після медикаментозної корекції відмічено значне покращення реологічних властивостей крові та мікроцир- куляції: зросли фотоплетизмографічний індекс на 86,7 \%, індекс еластичності на 32,6 \%, капілярний градієнт на 61,3 \%.

Висновки. Комплексна профілактика венозного тромбоемболізму сприяє зниженню гіперко- 
агуляції крові, нормалізації коагуляційного гемостазу покращенню реологічних властивостей крові, а звідси і тканинної мікроциркуляції, зокрема в ураженій патологічним процесом нижній кінцівці.

\section{СПИСОК ЛІТЕРАТУРИ}

1. Березницький Я. С. Ефективність тромбопрофілактики у хворих із гострою абдомінальною патологією (аналіз 5 років) / Я. С. Березницький, Г. Ю. Хапатько, С. М. Куриляк // Львівський медичний часопис. - 2008. - T. XIV, № 3. - С. 11-13.

2. Гавриленко А. В. Результаты комплексного лечения больных с хронической ишемией нижних конечностей с использованием генных технологий стимуляции ангиогенеза / А. В. Гавриленко, Д. А. Воронов // Ангиология и сосудистая хирургия. - 2013. - Т. 19. - С. 66-67.

3. Кириенко А. И. Тромбозы и тромбоэмболии. Профилактика венозных тромбоэмболических осложнений в хирургической практике / А. И. Кириенко // Consil med. - 2006. Vol. 8 (7). - P. 1-5.
Перспективи подальших досліджень. Розроблення схем комплексної профілактики венозного тромбоемболізму у хворих із посттромботичним синдромом у стадії оклюзії.

4. Матвійчук Б. О. Оцінка ризику венозних тромбозів i емболій в ургентній абдомінальній хірургії / Б. О. Матвійчук, Н. Р. Федчишин, О. Б. Матвійчук // Український журнал хірургії. - 2009. - № 1. - С. 85-89.

5. Неотложная хирургия органов брюшной полости (клиническое руководство) / [Ахметишин Р. Л., Болдижар А. А., Болдижар П. А. и др.] ; под ред. П. Г. Кондратенко, В. И. Русина. - Донецк : Издатель Заславский А. Ю., 2013. - С. 157-158.

6. Prevention of venous thromboembolism / W. H. Geerts, J. A. Heit, G. P. Clagett [et al.] // Chest. - 2001. - Vol. 119. - P. 132-175.

7. Prevention of Venous Thromboembolism. The Seventh ACCP Conference on Antithrombotic and Thrombolytic Therapy / W. H. Geerts, G. F. Pineo, J. A. Heit [et al.] // CHEST. - 2004. Vol. 126. - P. 338-400. 